\title{
Evaluation of antimicrobial action of silver composite microspheres based on styrene-divinylbenzene copolymer
}

\author{
Maria Aparecida Larrubia Granado Moreira Rodrigues Mandu'1 Luciana da Cunha Costa², \\ Rodrigo Bernardes Tiosso ${ }^{1}$, Rômulo Pires Grasso ${ }^{1}$ and Mônica Regina da Costa Marques Calderari* \\ 'Programa de Pós-graduação em Química, Universidade do Estado do Rio de Janeiro - UERJ, \\ Rio de Janeiro, RJ, Brasil \\ 2Programa de Pós-graduação em Ciência e Tecnologia Ambiental, Centro Universitário Estadual da Zona \\ Oeste - UEZO, Rio de Janeiro, RJ, Brasil \\ *monicamarques@uerj.br
}

\begin{abstract}
This article reports the evaluation of the antimicrobial activity of a silver composite based on sulfonic resin. The antimicrobial action of the composite was evaluated against Escherichia coli, Pseudomonas aeruginosa and Staphylococcus aureus through plate, batch and colunm experiments. In batch studies, the efficiency of the composite was evaluated as a function of composite mass, bacterial concentration and contact time. We also developed a method to evaluate the antimicrobial activity of this composite using column tests. The antimicrobial activity of the composite was similar against the three bacteria in halo inhibition and batch experiments. The antibacterial activity was $100 \%$ against all bacteria above $0.20 \mathrm{~g}$ of composite and for all concentrations of bacteria studied. Column studies showed that the composite $(1 \mathrm{~g})$ had $100 \%$ action against $48 \mathrm{~cm}^{3}$ of $S$. aureus and $55 \mathrm{~cm}^{3}$ of E. coli and $P$. aeruginosa suspensions $\left(10^{5}\right.$ cells $\left.\mathrm{mL}^{-1}, 50 \mathrm{~cm}^{3} \mathrm{~min}^{-1}\right)$.
\end{abstract}

Keywords: biocidal polymers, styrene-divinylbenzene copolymers, sulfonic resins, silver composites.

How to cite: Mandu, M. A. L. G. M. R., Costa, L. C., Tiosso, R. B., Grasso, R. P., \& Calderari, M. R. C. M. (2019). Evaluation of antimicrobial action of silver composite microspheres based on styrene-divinylbenzene copolymer. Polimeros: Ciência e Tecnologia, 29(4), e2019052. https://doi.org/10.1590/0104-1428.00219

\section{Introduction}

Among the various antimicrobial materials are nanomaterials, antimicrobial peptides and antimicrobial polymers ${ }^{[1]}$. Antimicrobial polymers have been extensively evaluated for disinfection of water ${ }^{[2-4]}$. They have many advantages over low molecular weight biocidal compounds, mainly greater stability with respect to volatilization, dissolution and diffusion to the environment ${ }^{[3,5]}$.

The formation of biofilms on solid surfaces is a concern in several fields, such as the pharmaceutical industry. In these biofilms, the microorganisms are much more resistant to disinfectant $\mathrm{s}^{[6]}$. Porous membranes used for water treatment in processes such as microfiltration, ultrafiltration and reverse osmosis are subject to membrane fouling and consequently biofilm formation ${ }^{[7]}$. Thus, a water pretreatment step with an antimicrobial polymer before traditional membrane treatment can reduce the formation of biofilms, consequently increasing the lifetimes of these membranes.

Crosslinked copolymer microspheres such as copolymers based on divinylbenzene have been extensively used as supports for chemical catalysts and biocatalysts ${ }^{[8,9]}$, ion imprinting polymers ${ }^{[10]}$, and introduction of magnetic particles ${ }^{[11-14]}$, adsorbents and absorbents ${ }^{[15,16]}$ and antimicrobial groups $^{[3,5,17-26]}$.

The introduction of antimicrobial groups in crosslinked copolymers is commonly achieved by chemical modification or impregnation of the antibacterial agent in the polymeric matrix $^{[3]}$. The polymeric supports employed most often are crosslinked beads made of divinylbenzene (DVB), and the biocidal groups studied are mainly ammonium and phosphonium quaternary groups ${ }^{[3,17,19,22]}$, charge transfer complexes involving iodine and quaternary ammonium groups $^{[3,17,23]}$, N-halamines ${ }^{[3,6]}$, sulfo-derivatives ${ }^{[3,5,18]}$ and metal particles ${ }^{[1-3,20,21,24-26]}$.

According to Munoz-Bonilla and Fernández-Garcia ${ }^{[2]}$, silver nanoparticles are the metal particles most commonly used as antimicrobial agents in polymeric nanocomposites. Also according to those authors, silver in its metallic state is ionized in the medium, releasing $\mathrm{Ag}^{+}$ions, and among other effects, the $\mathrm{Ag}^{+}$ions bind to thiol groups in essential proteins, provoking structural changes in the cell wall that can cause death. The introduction of silver particles in crosslinked Sty-DVB copolymers can be considered a good strategy to prepare antimicrobial polymers. Silver has strong antimicrobial activity against a broad spectrum of microorganisms $s^{[2,24-26]}$ and Sty-DVB copolymers are inert supports with good mechanical stability and easy synthesis.

Santa Maria et al. ${ }^{[21]}$ prepared composites through impregnation of silver nanoparticles in styrene-divinylbenzene copolymers containing sulfonic acid groups. The biocidal activity was evaluated against $E$. coli using the column 
method. This activity of silver nanocomposites varied from 54 to $100 \%$. However, the biocidal activity of the nanocomposite was not evaluated against other bacteria by applying the plate and batch methods. Column experiments were realized in syringes similar to those used in solid phase extraction (SPE), without control of flow rate.

More recently, Yee et al. ${ }^{[24]}$ prepared silver nanocomposites based on a commercial ion exchange resin (the sulfonic resin Dowex 50WX8-400) as support. This resin was impregnated with silver ions and reduced with sodium borohydride. The authors observed that the nanocomposite inhibited the attachment of Histioteuthis pacifica biofilms. The biocompatibility evaluations showed that this silver nanocomposite was not toxic to human cells.

In this work, we investigated the antimicrobial activity of silver composite microspheres prepared by impregnation of silver particles in a sulfonic resin. The antimicrobial experiments were performed against three bacteria of medical importance: E. coli and P. aeruginosa (Gram-negative bacteria) and $S$. aureus (Gram-positive bacterium), by applying the plate, batch and column methods. A method was also developed to evaluate the antimicrobial activity of polymeric resins by using column experiments. Some data obtained from the column experiments, such as the breakthrough point, are important for practical application of this type of material on a macro scale.

\section{Materials and Methods}

\subsection{Chemicals}

The ion-exchange resin Lewatit VPOC1800 was donated by Lanxess - Bayer Chemicals. Nutrient broth, nutrient agar, cetrimide agar base, Levines EMB agar, mannitol salt agar base, tryptone soy agar and tryptone soy broth for use in microbiological culture media were purchased from HiMedia Laboratories PVT Limited (Mumbai, India). The Staphylococcus aureus ATCC 6538, Escherichia coli ATCC 11229 and Pseudomonas aeruginosa ATCC 15442 strains were donated by the Microorganism Collection for Sanitary Vigilance Reference (INCQS-FIOCRUZ, Rio de Janeiro, RJ). Other reagents and solvents were purchased from Sigma-Aldrich Brazil Co. Ltda. (Rio de Janeiro, Brazil) and used as received.

\subsection{Preparation of the silver composite}

The silver composite was prepared by impregnation of silver particles in commercial Lewatit VPOC1800 sulfonic resin according to the method previously described ${ }^{[21]}$.

Sulfonic resin (in sodium form) was pretreated with an aqueous solution of $2 \% \mathrm{v} / \mathrm{v} \mathrm{HCl}$ for $24 \mathrm{~h}$, followed by washing with deionized water until neutral $\mathrm{pH}$, then acetone $\left(300 \mathrm{~cm}^{3}\right)$, and drying at $60{ }^{\circ} \mathrm{C}$ for $24 \mathrm{~h}$. The impregnation of silver particles was performed with a solution of $7.7 \%$ w/v $\mathrm{AgNO}_{3}$ acidified with $0.1 \mathrm{~cm}^{3}$ of $\mathrm{HNO}_{3}$ in a sealed flask protected from light for $48 \mathrm{~h}$. According to the manufacturer, the sulfonic resin VPOC1800 has a cation exchange capacity of $4.4 \mathrm{mEq} \mathrm{g}^{-1}$, so it was used with an excess of $10 \mathrm{x} \mathrm{of} \mathrm{Ag}^{+}$ to $\mathrm{H}^{+}$ions.

After this, the resin was washed with deionized water until negative test with $1 \% \mathrm{w} / \mathrm{v} \mathrm{NaCl}$. The reduction step was performed employing $2 \mathrm{~mol} \mathrm{dm}^{-3}$ of hydroxylamine chloride, gelatin and 2-hydroxy-ethyl cellulose. The beads were washed repeatedly with deionized water until neutral $\mathrm{pH}$, followed by ethanol $\left(300 \mathrm{~cm}^{3}\right)$, and dried at $60^{\circ} \mathrm{C}$ for $48 \mathrm{~h}$.

\subsection{Characterization of the silver composite}

Surface area and pore volume of the sulfonic resin and composite derived from it were determined by nitrogen adsorption measurements, according to the BET and BJH methods (Micrometrics ASAP 2010 system). TG and DTG curves were obtained using a TA Q50 instrument in a temperature range of $30-700{ }^{\circ} \mathrm{C}$ at a constant heating rate of $20{ }^{\circ} \mathrm{C} \mathrm{min}^{-1}$ under nitrogen atmosphere and a flow rate of $100 \mathrm{~cm}^{3} \mathrm{~min}^{-1}$. The shape and surface texture of the materials were monitored with an FEI Quanta 400 scanning electron microscope (SEM) operating at $20 \mathrm{keV}$, with magnification of $10000 \mathrm{x}$. The presence of metal particles was confirmed by energy dispersive X-ray spectrometry using an EDX microprobe.

\subsection{Antibacterial experiments}

\subsubsection{Preliminary experiments}

Sterility of the culture medium was verified by incubation of $5 \%$ of the solutions at $37^{\circ} \mathrm{C}$ for $48 \mathrm{~h}$ before the experiments.

Lyophilized Staphylococcus aureus ATCC 6538, Escherichia coli ATCC 11229 and Pseudomonas aeruginosa ATCC 15442 bacteria were hydrated and cultured on specific media according to Table 1.

Bacterial glycerol stocks were prepared and kept frozen at $-4{ }^{\circ} \mathrm{C}$. Aliquots of $25 \mu \mathrm{L}$ of these bacterial stocks were pipeted to fresh broth $(3 \mathrm{~mL})$ and incubated at $37{ }^{\circ} \mathrm{C}$ for $24 \mathrm{~h}$. Then, $10 \mu \mathrm{L}$ samples of these cultures were seeded on agar slants, and these cultures were used to prepare suspensions in saline solutions $(3 \mathrm{~mL}, 0.9 \% \mathrm{~m} / \mathrm{v})$. These suspensions were adjusted to $3 \times 10^{8}$ cells $/ \mathrm{mL}$, where the concentration was determined by turbidimetry with a spectrophotometer (Hach DR 5000, $600 \mathrm{~nm}$ ) employing the McFarland standard (chemical solution of barium chloride and sulfuric acid). These suspensions were diluted to attain the other concentrations.

All antimicrobial experiments were accompanied by negative, positive and environmental controls. In the positive control experiments, bacterial suspensions were cultivated without sulfonic resin and silver composite. In the negative control experiments, bacterial suspensions were placed in

Table 1. Conditions for Hydration and Cultivation of Bacterial Strains.

\begin{tabular}{lcc}
\hline \multicolumn{1}{c}{ Bacterial strains } & Hydration medium & Cultivation medium \\
\hline Staphylococcus aureus ATCC 6538 & Tryptone soy broth & Tryptone soy agar \\
Escherichia coli ATCC 11229 & Tryptone soy broth & Tryptone soy broth \\
Pseudomonas aeruginosa ATCC 15442 & Nutrient broth & Nutrient agar \\
\hline
\end{tabular}


contact with Lewatit VPOC 1800 sulfonic resin. Environmental control experiments were performed by putting plates with culture medium under a laminar flow hood.

\subsubsection{Plate method}

Bacterial cultures of $S$. aureus, E. coli and P. aeruginosa $\left(3 \times 10^{8}\right.$ cells $\left.\mathrm{mL}^{-1}\right)$ were spread onto plates with agar nutrient medium. The center of these plates was filled with silver composites. The plates were incubated at $37{ }^{\circ} \mathrm{C}$ for $48 \mathrm{~h}$. After this, the inhibition zone was measured. Unmodified sulfonic resins were used as controls in the experiments.

\subsubsection{Batch experiments}

Bacterial suspensions of $S$. aureus, E. coli and P. aeruginosa were placed in glass flasks containing $2 \mathrm{~mL}$ of sterile $0.9 \%$ saline solution and a determined mass of composite. The composite and bacteria were maintained in contact for varied periods of time. The experiments of variation of composite mass were conduced employing bacterial suspensions with concentration of $10^{5}$ cells $\mathrm{mL}^{-1}$, contact time of 30 minutes and varied composite mass (0.05-0.8 g). The experiments involving variation of bacterial suspension concentrations were realized employing $0.2 \mathrm{~g}$ of composite, contact time of 30 minutes and varied concentrations of bacteria $\left(10^{3}-10^{7}\right.$ cells $\left.\mathrm{mL}^{-1}\right)$. The experiments investigating variation of contact time were conduced employing a bacterial suspension of $10^{5}$ cells $\mathrm{mL}^{-1}, 0.2 \mathrm{~g}$ of silver composite and contact time of 30 to 180 seconds. Each experiment was conducted in a glass flask and all experiments were realized in triplicate. Aliquots of $1 \mathrm{~mL}$ of supernatant were plated on selective media and kept at $37^{\circ} \mathrm{C}$. After $48 \mathrm{~h}$, the colonies formed (CFU) were counted. Unmodified sulfonic resins were used as controls in the experiments. The bactericidal activity of the polymers was estimated by calculating the decrease in the number of bacteria according to Equation $1^{[17,19]}$.

$$
\text { Antimicrobial capacity }=100 \times\left(\mathrm{CFU}_{\mathrm{i}}-\mathrm{CFU}_{\mathrm{f}}\right) / \mathrm{CFU}_{\mathrm{i}}
$$

where $\mathrm{CFU}_{\mathrm{i}}=$ colonies formed before contact between bacterial suspensions and polymers; $\mathrm{CFU}_{\mathrm{f}}=$ colonies formed after contact between bacterial suspensions and polymers.

\subsubsection{Column experiments}

Column experiments were conducted in acrylic columns measuring $1.9 \mathrm{~cm}$ (inside diameter) and $30 \mathrm{~cm}$ (height) coupled to a peristaltic pump (Exatta Model A305). The column was packed with $30 \mathrm{~g}$ of resin $\left(13 \mathrm{~cm}^{3}\right)$ and the resin was submitted to swelling with sterile distilled water $\left(60 \mathrm{~cm}^{3}\right)$ for $24 \mathrm{~h}$. After being eluted through the column, this water was analyzed by ion exchange chromatography (IEC) (DIONEX, Model ICS 300 DP). No silver ions were detected in this water. After the swelling period, suspensions of each bacterium (S. aureus, E. coli or P. aeruginosa) of $10^{5}$ cells $\mathrm{mL}^{-1}$ were passed through the column at a flow rate of $50 \mathrm{~mL} \mathrm{~min}^{-1}$. Each experiment with a different bacterium was performed in a different column. For determination of the breakthrough curve, the elute was collected from the column effluent at intervals of 1-2 minutes. Aliquots of these suspensions were plated on LB nutrient medium and kept at $37^{\circ} \mathrm{C}$. After $48 \mathrm{~h}$, the colonies formed (CFU) were counted. Unmodified sulfonic resins were used as controls in the experiments. The breakthrough curve provided data on the breakthrough point $\mathrm{V}_{\mathrm{p}}$ (the point when the cells are first detected in the column effluent) and working biocidal activity $\mathrm{C}_{\mathrm{r}}$ (Equation 2$)^{[16]}$.

$$
\mathrm{Cr}=\frac{\mathrm{V}_{\mathrm{p}} \bullet \mathrm{C}_{\mathrm{o}}}{\mathrm{V}_{\mathrm{j}}}
$$

where $\mathrm{V}_{\mathrm{p}}=$ effluent volume at the breakpoint $\left(\mathrm{cm}^{3}\right) ; \mathrm{V}_{\mathrm{j}}=$ volume of biocidal resin in the column $\left(\mathrm{cm}^{3}\right)$; and $\mathrm{C}_{\mathrm{o}}=$ initial bacterial concentration (cells $\mathrm{cm}^{-3}$ ).

\subsubsection{Statistical analysis}

All the tests results were compared by one-way analysis of variance (ANOVA) using the BioEstat software (version 5.0).

\section{Results and Discussion}

\subsection{Characterization of silver composite}

The silver composite was prepared by treatment of Lewatit VPOC1800 sulfonic resin with $\mathrm{AgNO}_{3}$ followed by reduction reaction with hydroxylamine chloride. These reactions caused a drastic reduction in surface area and pore volume of the sulfonic resin (Table 2), indicating the agglomeration of silver particles in pores and channels of the resin ${ }^{[21]}$. The occurrence of impregnation was also evidenced by TGA (Table 2). The anchorage of silver particles increased the onset temperature and residual mass of the polymeric matrix, indicating that this anchorage increases the thermal resistance of the sulfonic resin. These results agree with other results of thermal decomposition of nanocomposites, demonstrating that the impregnation of metal particles improves the thermal resistance of the polymeric support ${ }^{[15]}$.

The SEM micrographs of the Lewatit VPOC1800 resin impregnated with silver nanoparticles (Figure 1) demonstrated that the nanoparticles were distributed on the beads surface. The presence of elemental silver on the surface of the composite was also investigated by EDS spectra (Figure 2), confirming the silver impregnation of the sulfonic resin surface.

\subsection{Plate method}

The silver nanocomposite and unmodified resin were evaluated for antibacterial activity by using the plate method (Figure 3). The inhibition zone was measured for three bacterial cultures: E. coli, S. aureus and P. aeruginosa.

\begin{tabular}{|c|c|c|c|c|}
\hline Materials & $\mathrm{S}\left(\mathrm{m}^{2} \mathrm{~g}^{-1}\right)^{\mathrm{a}}$ & $V p\left(\mathrm{~cm}^{3} \mathrm{~g}^{-1}\right)^{b}$ & T onset $\left({ }^{\circ} \mathbf{C}\right)^{c}$ & Residue (\%) \\
\hline VPOC 1800 & 3.789 & 0.02 & 344 & 39.2 \\
\hline VPOC $1800 / \mathrm{Ag}$ & 0.038 & $\mathrm{nd}^{\mathrm{d}}$ & 463 & 57.1 \\
\hline
\end{tabular}

Table 2. Morphological characteristics and TGA data for the resin Lewatit VPOC1800 before and after impregnation with silver.

${ }^{\mathrm{a} S}$ : surface area (BET-ASAP); ${ }^{\mathrm{b}} \mathrm{Vp}$ : pore volume (BJH-ASAP); ${ }^{\mathrm{c}}$ thermogravimetric analysis (TGA); ${ }^{\mathrm{d}}$ not detected. 
(a)

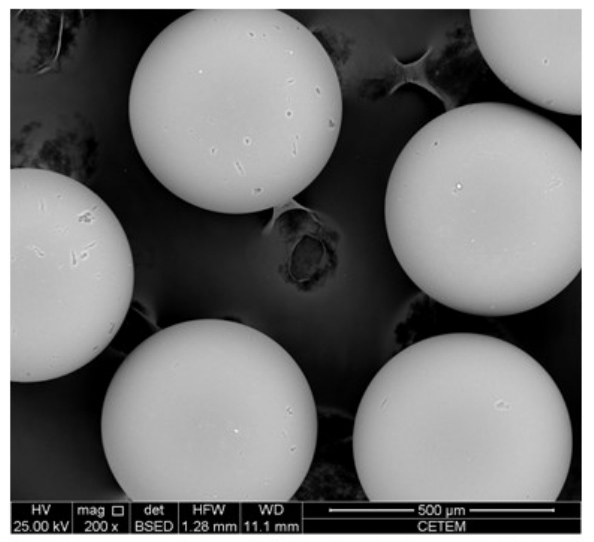

(c)

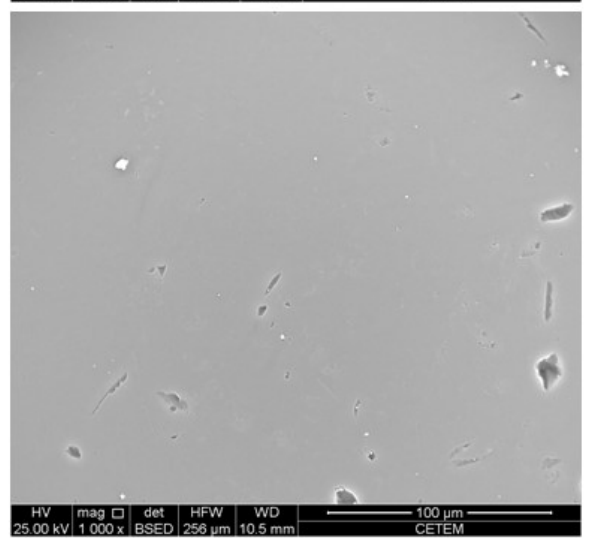

(b)

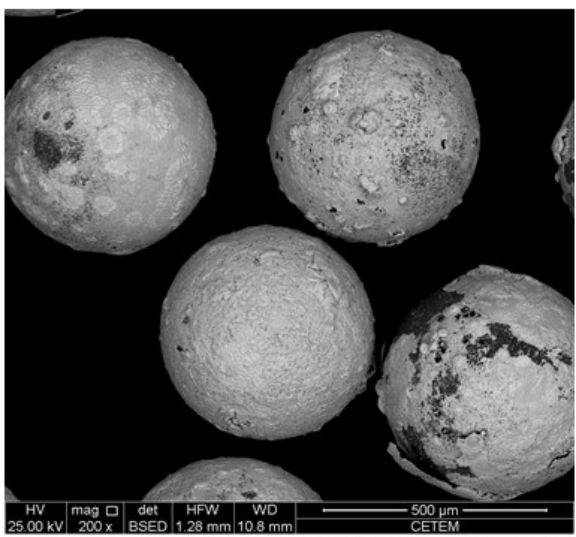

(d)

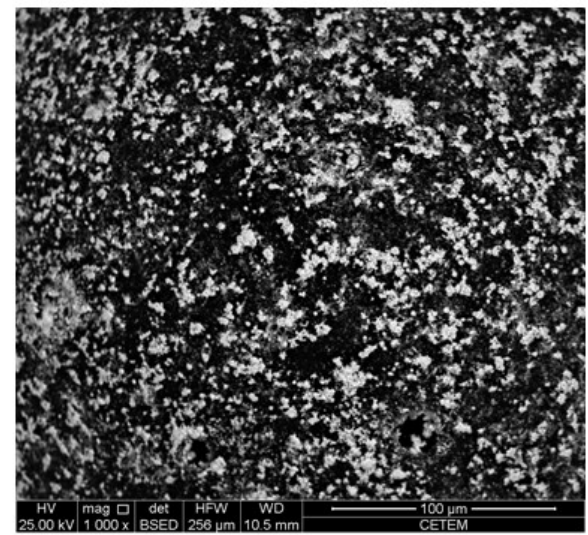

Figure 1. Scanning electron micrographs of Lewatit VPOC1800 resin before (a, c) and after (b, d) impregnation with silver.

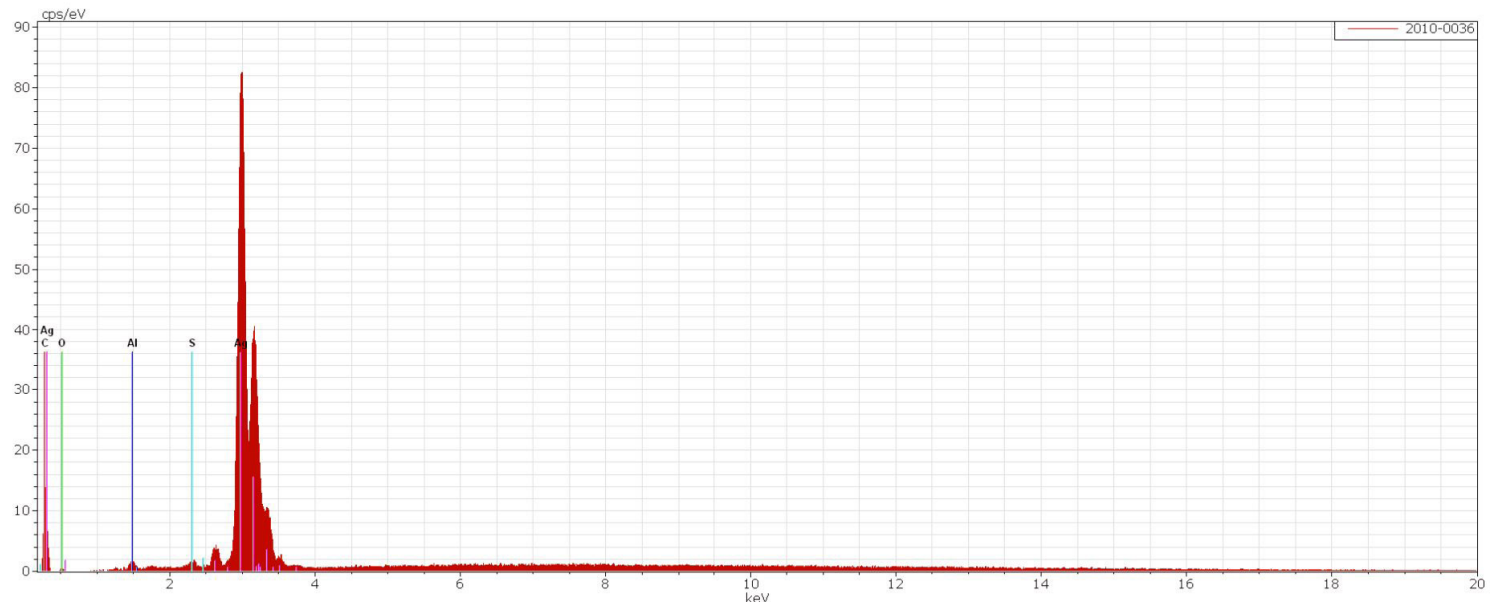

Figure 2. EDS spectra of silver composite.

As expected, the unmodified resin did not have antimicrobial action against the three bacterial species analyzed. Santa Maria et al. ${ }^{[21]}$ also observed that the unmodified sulfonic resin (Lewatit VPOC1800) did not show antimicrobial action against $E$. coli. However, E. coli had a zone diameter of $1.4 \pm 0.3 \mathrm{~cm}, P$ aeruginos $a$ had a zone diameter of $1.8 \pm 0.2 \mathrm{~cm}$ and $S$. aureus showed a zone diameter of $1.3 \pm 0.2 \mathrm{~cm}$ for the silver nanocomposite. These data demonstrate the bacteriostatic effect of silver composite, i.e., the composites ability to inhibit bacterial growth around polymeric particles. Kamrupi et al. ${ }^{[27]}$ also observed that nanocomposites of polystyrene containing silver nanoparticles had inhibitory effect against four bacterial species studied: Pseudomonas fluorescens BS3, Bacillus circulens BP2, Eschericia coli and Staphylococcus aureus. However, those authors did not measure the inhibition halo of the bacteria.

Statistical analysis of the data of the inhibition halo observed in this study, performed by one-way analysis of 


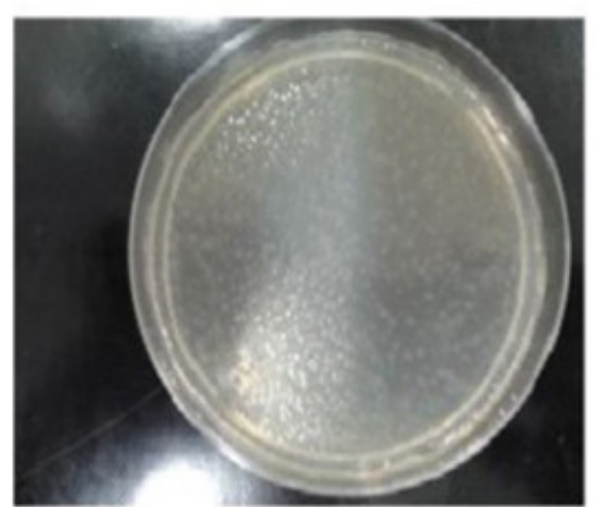

a

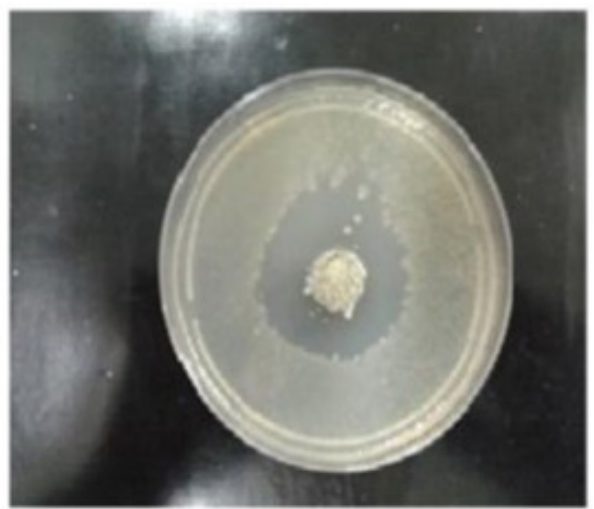

b

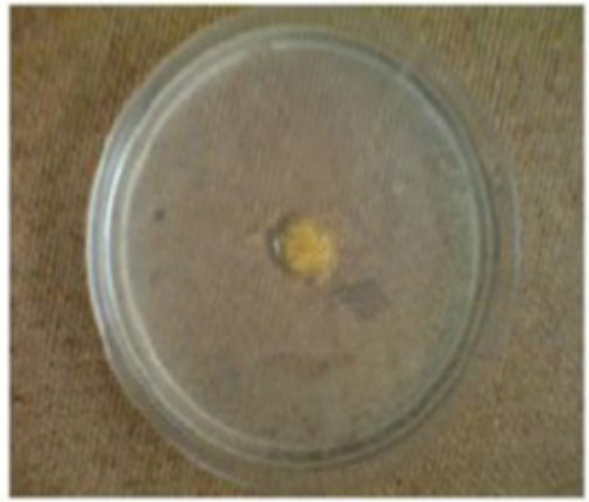

C

Figure 3. Plate test for P. aeruginosa: (a) positive control, indicating bacteria growing on agar nutrient medium without nanocomposite (b) inhibition halo formed by composite in P. aeruginosa culture (c) negative control, indicating absence of inhibition halo for Lewatit VPOC1800 not modified with silver particles.

variance, demonstrated that the difference in zone diameter was not significant $(p=0.1361$ and $\alpha=0.01$, i.e., $p>\alpha)$. Since Gram-negative bacteria (such as E. coli and P. aeruginosa) possess an additional cell wall that Gram-positive bacteria (such as $S$. aureus) do not have, we expected the biocidal action of the silver nanocomposite would be different for these two types of bacteria ${ }^{[27]}$. However, unlike expected, it was not possible to observe differences in the inhibition zones of the silver composite against the three bacteria species, i.e., no difference was observed in the halo test.

\subsection{Batch experiments}

\subsubsection{Mass of composite}

In this study, bacterial suspensions were used with concentration of $10^{5}$ cells $\mathrm{mL}^{-1}$, contact time of 30 minutes and composite masses of 0.05-0.80 g. As expected, an increase of composite mass provoked an increase of the biocidal activity. In general, the antibacterial activity was complete $(100 \%)$ for all bacteria above $0.20 \mathrm{~g}$ of composite. The ANOVA results $(\alpha=0.05)$ indicated that the variation of composite mass was highly significant $(p<0.0001)$, whereas the variation of bacteria was not significant $(p>0.5)$. The Tukey test indicated that the mass variation until $0.15 \mathrm{~g}$ was significant and increased the antimicrobial activity. Above $0.15 \mathrm{~g}$, the differences in removal percentages were not significant (Table 3 ).
The antimicrobial action of silver composite was similar to Gram-positive and Gram-negative bacteria, confirming the results of the plate experiments.

The silver composite is a bactericide, i.e., this composite causes damage to bacteria that leads to their death, such as by metabolic inhibition, loss of membrane integrity or coagulation of intracellular material. This composite may have realeased the silver ions in the medium (a demand-release disinfectant) or acted via contact between bacteria and silver particles trapped in polymeric matrix, causing damage to the bacteria (contact disinfectant), leading to death ${ }^{[28]}$. In both cases, the increasing mass of composite would cause rising biocidal activity.

\subsubsection{Concentration of bacteria}

We employed bacterial suspensions of $10^{3}$ to $10^{7}$ cells $\mathrm{mL}^{-1}$, $0.2 \mathrm{~g}$ of silver composite and contact time of 30 minutes (Table 4). Valle et al. ${ }^{[17,19]}$ demonstrated that the biocidal activity of vinyl pyridine copolymers containing quaternary ammonium groups and charge transfer complexes with iodine was influenced by concentration of bacterial suspension in contact with these polymers, and there was a significant reduction of the biocidal activity with high concentrations of bacterial suspensions $\left(10^{6}\right.$ and $10^{7}$ cells $\left.\mathrm{mL}^{-1}\right)$. Souza et al. ${ }^{[5]}$ also observed that the biocidal activity of Sty-DVB copolymers with phosphoryl and sulfophosphoryl groups was influenced by concentration of bacterial suspension 
Table 3. Antimicrobial activity (\%) of silver composite with varying mass (g).

\begin{tabular}{|c|c|c|c|c|c|c|}
\hline \multirow{2}{*}{$\frac{\text { Bacteria }}{\text { Pseudomona aueruginosa }}$} & \multirow{2}{*}{$\begin{array}{c}\text { Mass (g) } \\
0.05\end{array}$} & \multicolumn{4}{|c|}{ CFU mL $\mathbf{L}^{-1}$} & \multirow{2}{*}{$\begin{array}{c}\begin{array}{c}\text { Antimicrobial } \\
\text { capacity (\%) }\end{array} \\
60\end{array}$} \\
\hline & & $6.50 \times 10^{4}$ & $5.20 \times 10^{4}$ & $5.80 \times 10^{4}$ & $6.40 \times 10^{4}$ & \\
\hline & 0.10 & $1.90 \times 10^{4}$ & $1.80 \times 10^{4}$ & $1.80 \times 10^{4}$ & $1.90 \times 10^{4}$ & 88 \\
\hline & 0.15 & $7.40 \times 10^{3}$ & $8.50 \times 10^{3}$ & $6.70 \times 10^{3}$ & $9.80 \times 10^{3}$ & 95 \\
\hline & 0.20 & 1.00 & 2.00 & 2.00 & 4.00 & 100 \\
\hline & 0.40 & 0.00 & 0.00 & 0.00 & 0.00 & 100 \\
\hline & 0.80 & 0.00 & 0.00 & 0.00 & 0.00 & 100 \\
\hline \multirow[t]{6}{*}{ Escherichia coli } & 0.05 & $6.80 \times 10^{4}$ & $7.00 \times 10^{4}$ & $6.67 \times 10^{4}$ & $5.94 \times 10^{4}$ & 55 \\
\hline & 0.10 & $1.80 \times 10^{4}$ & $1.60 \times 10^{4}$ & $1.19 \times 10^{4}$ & $1.63 \times 10^{4}$ & 90 \\
\hline & 0.15 & $8.20 \times 10^{3}$ & $9.15 \times 10^{3}$ & $9.60 \times 10^{3}$ & $1.11 \times 10^{4}$ & 94 \\
\hline & 0.20 & 0.00 & 0.00 & 2.00 & 1.00 & 100 \\
\hline & 0.40 & 1.00 & 1.00 & 2.00 & 1.00 & 100 \\
\hline & 0.80 & 0.00 & 0.00 & 0.00 & 0.00 & 100 \\
\hline \multirow[t]{6}{*}{ Staphilococcus aureus } & 0.05 & $8.80 \times 10^{4}$ & $7.60 \times 10^{4}$ & $6.70 \times 10^{4}$ & $8.40 \times 10^{4}$ & 47 \\
\hline & 0.10 & $4.40 \times 10^{4}$ & $3.00 \times 10^{4}$ & $3.00 \times 10^{4}$ & $4.30 \times 10^{4}$ & 74 \\
\hline & 0.15 & $2.00 \times 10^{4}$ & $1.50 \times 10^{4}$ & $1.60 \times 10^{4}$ & $1.00 \times 10^{4}$ & 90 \\
\hline & 0.20 & $2.50 \times 10^{2}$ & $3.80 \times 10^{2}$ & $4.90 \times 10^{2}$ & 1.00 & 100 \\
\hline & 0.40 & 1.00 & 3.00 & 2.00 & 1.00 & 100 \\
\hline & 0.80 & 0.00 & 0.00 & 0.00 & 0.00 & 100 \\
\hline
\end{tabular}

Analytic conditions: Initial concentration of bacteria, $10^{5}$ cells mL $\mathrm{mL}^{-1}$; contact time of 30 minutes; and composite masses of $0.05-0.80 \mathrm{~g}$. CFU: number of colonies formed after contact between bacterial suspensions and polymer.

Table 4. Animicrobial activity (\%) of silver composite with varying bacterial concentrations $\left(\mathrm{CFU} \mathrm{mL} \mathrm{mL}^{-1}\right)$.

\begin{tabular}{|c|c|c|c|c|c|c|}
\hline \multirow{2}{*}{$\begin{array}{c}\text { Bacterial } \\
\text { Pseudomona aueruginosa }\end{array}$} & \multirow{2}{*}{$\begin{array}{c}\begin{array}{c}\text { Concentration } \\
\left(\mathbf{C F U} \mathbf{~ m L}^{-1}\right)\end{array} \\
1.50 \times 10^{3}\end{array}$} & \multicolumn{4}{|c|}{$\mathrm{CFU} \mathrm{mL}^{-1}$} & \multirow{2}{*}{$\begin{array}{c}\begin{array}{c}\text { Antimicrobial } \\
\text { capacity }(\%)\end{array} \\
100\end{array}$} \\
\hline & & 0.00 & 1.00 & 1.00 & 0.00 & \\
\hline & $1.50 \times 10^{4}$ & 0.00 & 0.00 & 0.00 & 0.00 & 100 \\
\hline & $1.50 \mathrm{x} 10^{5}$ & 1.00 & 0.00 & 0.00 & 1.00 & 100 \\
\hline & $1.50 \mathrm{x} 10^{6}$ & 0.00 & 0.00 & 1.00 & 2.00 & 100 \\
\hline & $1.50 \times 10^{7}$ & 50.00 & 67.00 & 30.00 & 77.00 & 100 \\
\hline \multirow[t]{5}{*}{ Escherichia coli } & $1.50 \times 10^{3}$ & 0.00 & 1.00 & 1.00 & 0.00 & 100 \\
\hline & $1.50 \times 10^{4}$ & 0.00 & 0.00 & 0.00 & 0.00 & 100 \\
\hline & $1.50 \times 10^{5}$ & 1.00 & 0.00 & 0.00 & 1.00 & 100 \\
\hline & $1.50 \times 10^{6}$ & 20.00 & 15.00 & 17.00 & 12.00 & 100 \\
\hline & $1.50 \times 10^{7}$ & 100.00 & 88.00 & 97.00 & 77.00 & 100 \\
\hline \multirow[t]{5}{*}{ Staphilococcus aureus } & $1.50 \mathrm{x} 10^{3}$ & 0.00 & 0.00 & 0.00 & 0.00 & 100 \\
\hline & $1.50 \times 10^{4}$ & 0.00 & 0.00 & 0.00 & 0.00 & 100 \\
\hline & $1.50 \times 10^{5}$ & 1.00 & 1.00 & 1.00 & 1.00 & 100 \\
\hline & $1.50 \times 10^{6}$ & 2.00 & 3.00 & 1.00 & 2.00 & 100 \\
\hline & $1.50 \times 10^{7}$ & 200.00 & 167.00 & 230.00 & 177.00 & 100 \\
\hline
\end{tabular}

Analytic conditions: composite mass of of $0.2 \mathrm{~g}$; contact time of 30 minutes; initial bacterial concentrations of $10^{3}$ to $10^{7}$ cells $\mathrm{mL}^{-1}$. CFU: number of colonies formed after contact between bacterial suspensions and polymer.

and noted a reduction of biocidal action of the polymers to bacterial suspensions with $10^{6}$ and $10^{7}$ cells $\mathrm{mL}^{-1}$. However, they observed that the variation in bacterial concentration did not cause a variation in biocidal activity of the silver composite. For the highest concentration of bacteria studied $\left(1.5 \times 10^{7}\right.$ cells $\left.\mathrm{mL}^{-1}\right)$, the biocidal activity was already $100 \%$.

\subsubsection{Contact time}

We used a bacterial suspension of $10^{5}$ cells $\mathrm{mL}^{-1}, 0.2 \mathrm{~g}$ of silver composite and contact times of 30 to 180 seconds (Table 5). A wide range of contact times between silver composite and bacterial suspensions was used in order to determine the minimum contact time between the suspensions and polymer needed to achieve maximum antimicrobial activity $(100 \%)$.
The variation in contact time caused an increase of antimicrobial activity of the composite against all bacteria studied. The ANOVA results $(\alpha=0.05)$ demonstrated that the variation in contact time was highly significant $(p<0.0001)$, whereas the variation of the type of bacterium was not significant $(p>0.5)$. The Tukey test indicated that the variation of contact time until 40 seconds was significant and contributed to increase biocidal activity, but above 40 seconds the differences in removal percentages were not significant.

After short contact time between composite and suspensions, the maximum biocidal activity was already reached. Our first hypothesis for this result was the release of silver from the polymeric structure as a function of contact time. This hypothesis was partially confirmed by plate 
Table 5. Antimicrobial activity (\%) of the silver composite with varying contact times (sec).

\begin{tabular}{|c|c|c|c|c|c|c|}
\hline \multirow{2}{*}{$\frac{\text { Bacteria }}{\text { Pseudomona aueruginosa }}$} & \multirow{2}{*}{$\frac{\text { Time (sec) }}{30}$} & \multicolumn{4}{|c|}{ CFU mL $\mathbf{m}^{-1}$} & \multirow{2}{*}{$\begin{array}{c}\begin{array}{c}\text { Antimicrobial } \\
\text { Capacity (\%) }\end{array} \\
87\end{array}$} \\
\hline & & $2.00 \times 10^{4}$ & $1.00 \times 10^{4}$ & $1.20 \times 10^{4}$ & $1.00 \times 10^{4}$ & \\
\hline & 40 & $2.50 \times 10^{2}$ & $1.20 \times 10^{2}$ & 95.00 & 80.00 & 99 \\
\hline & 60 & 2.00 & 0.00 & 10.00 & 0.00 & 99 \\
\hline & 120 & 1.00 & 0.00 & 0.00 & 0.00 & 99 \\
\hline & 180 & 0.00 & 0.00 & 0.00 & 0.00 & 100 \\
\hline \multirow[t]{5}{*}{ Escherichia coli } & 30 & $1.00 \times 10^{4}$ & $1.5 \times 10^{4}$ & $1.6 \times 10^{4}$ & $1 \times 10^{4}$ & 87 \\
\hline & 40 & $2.5 \times 10^{2}$ & $3.8 \times 10^{2}$ & $4.9 \times 10^{2}$ & 1 & 99 \\
\hline & 60 & 50.00 & 2.00 & 4.00 & 1.00 & 99 \\
\hline & 120 & 0.00 & 0.00 & 0.00 & 0.00 & 100 \\
\hline & 180 & 0.00 & 0.00 .00 & 0.00 & 0.00 & 100 \\
\hline \multirow[t]{5}{*}{ Staphilococcus aureus } & 30 & $2 \times 10^{4}$ & $1.5 \times 10^{4}$ & $1.6 \times 10^{4}$ & $1.00 \times 10^{4}$ & 84 \\
\hline & 40 & $2.5 \times 10^{2}$ & $3.8 \times 10^{2}$ & $2.9 \times 10^{2}$ & $1.00 \times 10^{2}$ & 99 \\
\hline & 60 & 1.00 & 5.00 & 2.00 & 1.00 & 99 \\
\hline & 120 & 0.00 & 0.00 & 0.00 & 0.00 & 100 \\
\hline & 180 & 0.00 & 0.00 & 0.00 & 0.00 & 100 \\
\hline
\end{tabular}

Analytic conditions: Initial bacterial concentration of $10^{5}$ cells $\mathrm{mL}^{-1}$; composite mass of $0.2 \mathrm{~g}$; contact times of:30-180 seconds. CFU: number of colonies formed after contact between bacterial suspensions and polymer.

studies, which demonstrated the composites ability to inhibit bacterial growth around polymeric particles. However, the subsequent column studies demonstrated the saturation point was reached only after passing a large volume of bacterial suspension through columns packed with composite, and it was not possible to observe a physical change of the composite, such as a discoloration, in these column studies. This indicates that the composite probably also acts as a contact biocide, where the electrostatic interation between silver ions and cell membrane causes damage to the bacteria leading to death ${ }^{[28,29]}$.

\subsection{Column experiments}

The antimicrobial activity of the polymeric resins, composites and nanocomposites was evaluated by plate and batch methods by varying the concentration of bacteria, contact time and resin mass, using $E$. coli (a Gram-negative bacterium ${ }^{[20,22]}$. The antimicrobial activity of these materials has not been sufficiently studied by column experiments, even though the use of these materials on a larger scale requires such studies.

Jandrey et al. ${ }^{[23]}$ developed a method for evaluation of biocidal activity of these polymers in column tests employing micro syringes $(1.0 \mathrm{~mL})$ filled with polymers $(130-250 \mathrm{mg})$. This method has been employed by several researchers, such as Souza et al. ${ }^{[5]}$, Valle et al. ${ }^{[17,19]}$, Costa et al..$^{[18]}$ and Santa Maria ${ }^{[21]}$. The method to evaluate the biocidal activity of polymers through column experiments applied in this work as well as the determination of the breakthrough point, saturation point and working biocidal activities, can be considered novel because they are not described in the previous literature.

Our column experiments were conducted in acrylic columns coupled to a peristaltic pump. Bacterial suspensions a $\left(4000 \mathrm{~cm}^{3}, 10^{5}\right.$ cells $\left.\mathrm{cm}^{-3}\right)$ were passed through the column packed with nanocomposite $(30 \mathrm{~g})$ at a flow rate of $50 \mathrm{~cm}^{3} \mathrm{~min}^{-1}$. Aliquots of these suspensions were plated on LB nutrient medium and kept at $37^{\circ} \mathrm{C}$, and after incubation the colonies formed (CFU) were counted. The breakthrough curve (Figure 4) and working biocidal activities of the silver composite were determined by employing a similar method to that used to determine the breakthrough curve and working activities of ion exchange resins ${ }^{[16]}$. The data obtained from these experiments are important for practical application of this type of material on a macro scale.

The breakthrough point is the point when the efficiency of the resin becomes lower than $100 \%$. This information is very important considering the need for water without pathogenic microorganisms. The breakthrough point occurred after passing $1650 \mathrm{~cm}^{3}$ of the suspensions of E. coli and $P$. aeruginosa and $1450 \mathrm{~cm}^{3}$ of the suspension of $S$ aureus through the column. These results indicate that each gram of composite has complete biocidal action against $55 \mathrm{~cm}^{3}$ of $E$. coli and $P$. aeruginosa suspensions and $48 \mathrm{~cm}^{3}$ of $S$. aureus suspension $\left(10^{5}\right.$ cells $\left.\mathrm{mL}^{-1}\right)$ at a flow rate of $50 \mathrm{~cm}^{3} \mathrm{~min}^{-1}$. The saturation point occurred after passing of $2250 \mathrm{~cm}^{3}$ of the suspension of $S$. aureus and $2450 \mathrm{~cm}^{3}$ of the suspensions of $E$. coli and $P$ aeruginosa through the column. The working biocidal activities of the silver composite were $126 \times 10^{5}$ cells $\mathrm{mL}^{-1}$ against $E$. coli and $P$. aeruginosa and $112 \times 10^{5}$ cells $\mathrm{mL}^{-1}$ against $S$. aureus.

According to Popa et al. ${ }^{[29]}$, the reduction of CFU as a function of exposure between polymer and bacterial suspensions can be interpreted as "an adsorption-like phenomenon", where the evolution is very similar to that of a monomolecular layer adsorption isotherm and culminates with the saturation process of the biocidal polymer with time.

The results indicated that the antimicrobial activity of the silver composite against $E$. coli and P. aeruginosa (Gram-negative bacteria) was higher than against $S$. aureus (Gram-positive bacterium).

Liang et al. ${ }^{[30]}$ reported that antimicrobial polymers with polyquat structures, such as polymers with ammonium and phosphonium groups, have higher antimicrobial action against Gram-positive bacteria. This can be parcially explained considering that Gram-negative bacteria possess a cell wall 


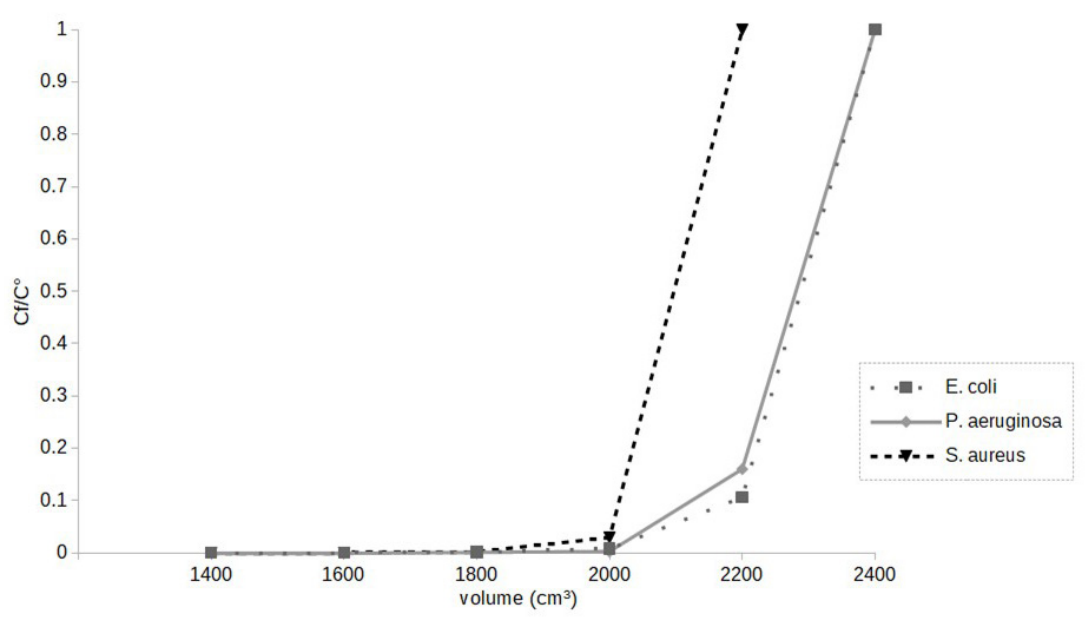

Figure 4. Breakthrough curve for the silver composite in contact with suspensions of S. aureus, E. coli or P. aeruginosa.

of peptidoglycan and LPS, which impairs the action of these polyquats. However these researchers have also reported that other antimicrobial polymers such as N-halamine polymers are more efficient against Gram-negative than Gram-positive bacteria. The antimicrobial action this of type of polymer involves direct transfer of oxidative halogen to the cell and cell inactivation.

It is well known that silver compounds are active against bacteria, viruses and fungi, but the bactericidal mechanism of these compounds is only partially understood. Probably the silver particles react with moisture and are ionized, releasing highly reactive $\mathrm{Ag}^{+}$ions on the beads' surface.

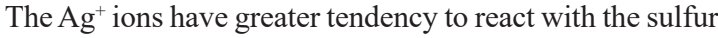
sites present in proteins, causing structural changes in the cell wall and also in the nuclear membranes, which causes cell death. In addition $\mathrm{Ag}^{+}$ions also form complexes with phosphorous sites present in DNA and RNA, inhibiting replication of microorganisms ${ }^{[31]}$. According to Thiel et al. ${ }^{[32]}$, the bactericidal action of silver particles can be attributed to electronic effects resulting from changes in the electronic structure of the surfaces of the silver particles. Silver particles act on the bacterial membrane causing destabilization of the plasma-membrane potential and reduction of the levels of intracellular ATP, resulting on bacterial death.

Our column data indicated that silver composite was more efficient against Gram-negative bacteria. Considering that silver particles provoke desestalization of the plasma-membrane potential and depletion of ATP levels and Gram-negative bacteria have an additional cell wall, it is possible that this type of bacterium is more susceptible to antimicrobial action of silver particles. Additional studies involving evaluation of the antimicrobial action of silver particles against Gramnegative and Gram-positive bacteria are needed.

\section{Conclusions}

Silver composite microspheres were prepared by impregnation of silver particles in the commercial sufonic resin Lewatit VPOC 1800. The impregnation reaction was achieved through reduction of $\mathrm{Ag}^{+}$ions with hydroxylamine in the presence of gelatin and 2-hydroxi-ethyl-celullose and characterized by thermogravimetry, SEM and EDS. The composite showed bactericidal activity against the three bacteria studied (E. coli, P. aeruginosa and S. aureus). The halo inhibition tests and batch experiments demonstrated that the antimcrobial activity of the composite was similar against the three bacterial species. However, the column studies indicated that the composite had stronger antimicrobial action against $S$. aureus than $E$. coli and $P$. aeruginosa. Each gram of the composite had complete antimicrobial action against $48 \mathrm{~cm}^{3}$ of $S$. aureus suspension and $55 \mathrm{~cm}^{3}$ of $E$. coli and $P$. aeruginosa suspensions $\left(10^{5}\right.$ cells $\left.\mathrm{mL}^{-1}\right)$ at a flow rate of $50 \mathrm{~cm}^{3} \mathrm{~min}^{-1}$. The working antimicrobial activities of the silver composite were $126 \times 10^{5}$ cells $\mathrm{mL}^{-1}$ against E. coli and $P$. aeruginosa and $111.5 \times 10^{5}$ cells $\mathrm{mL}^{-1}$ against $S$. aureus. The method to evaluate the biocidal activity of polymers through column experiments reported here as well as the determination of the breakthrough point, saturation point and working biocidal activities can be considered novel and are important for practical application of this type of material on a macro scale.

These results indicated that each gram of composite has complete biocidal action against $55 \mathrm{~cm}^{3}$ of E. coli and $P$. aeruginosa suspensions and $48 \mathrm{~cm}^{3}$ of $S$. aureus suspension $\left(10^{5}\right.$ cells $\left.\mathrm{mL}^{-1}\right)$ at a flow rate of $50 \mathrm{~cm}^{3} \mathrm{~min}^{-1}$

\section{Acknowledgements}

This study was financed in part by the Coordenação de Aperfeiçoamento de Pessoal de Nível Superior - Brazil (CAPES) - Finance Code 001. We also thank Fundação de Amparo a Pesquisa do Estado do Rio de Janeiro (FAPERJ) and Conselho Nacional de Desenvolvimento Científico e Tecnológico - CNPq for financial support and the companies Petroflex, Nitriflex and Metacril for donating the monomers.

\section{References}

1. Munoz-Bonilla, A., \& Fernández-Garcia, M. (2018). Poly(ionic liquid)s as antimicrobial materials. European Polymer Journal, 105(1), 135-149. http://dx.doi.org/10.1016/j. eurpolymj.2018.05.027. 
2. Munoz-Bonilla, A., \& Fernández-Garcia, M. (2012). Polymeric materials with antimicrobial activity. Progress in Polymer Science, 37(2), 281-339. http://dx.doi.org/10.1016/j. progpolymsci.2011.08.005.

3. Costa, L. C., Mandu, M. A. L. G. M. R., Santa Maria, L. C., \& Marques, M. R. C. (2015). Resinas poliméricas reticuladas com ação biocida: atual estado da arte. Polímeros: Ciencia e Tecnologia, 25(4), 414-423. http://dx.doi.org/10.1590/010414281739.

4. Kawabata, N. (1992). Capture of micro-organisms and viruses by pyridinium-type polymers and application to biotechnology and water purification. Progress in Polymer Science, 17(1), 1-34. http://dx.doi.org/10.1016/0079-6700(92)90015-Q.

5. Souza, M. A. V., Santa Maria, L. C., Costa, L. C., Galvão, R. C., Hui, W. S., \& Merçon, F. (2012). Evaluation of the biocide activity of phosphorylated and sulfophosphorylated resins. Materials Letters, 74(1), 121-124. http://dx.doi.org/10.1016/j. matlet.2012.01.093.

6. Jing, Z., Xiu, K., Ren, X., \& Sun, Y. (2018). Cationic polymeric $\mathrm{N}$-halamines bind onto biofilms and inactivate adherent bacteria. Colloids and Surfaces. B, Biointerfaces, 166(1), 210-217. http:// dx.doi.org/10.1016/j.colsurfb.2018.03.028. PMid:29597154.

7. Saeki, D., Nagashima, Y., Sawada, I., \& Matsuyama, H. (2016). Effect of hydrophobicity of polymer materials used for water purification membranes on biofilm formation dynamics. Colloids and Surfaces A, Physicochemical and Engineering Aspects, 506(1), 622-628. http://dx.doi.org/10.1016/j.colsurfa.2016.07.036.

8. Aguiar, M. A., Souza, A. L. F., Galdino, F. S., Silva, M. M. C., Teixeira, V. G., \& Lachter, E. R. (2017). Sulfonated poly(divinylbenzene) and poly(styrene-divinylbenzene) as catalysts for esterification of fatty acids. Renewable Energy, 114, 725-732. http://dx.doi.org/10.1016/j.renene.2017.07.084.

9. Pinto, M. C. C., Souza, N. L. S., Cipolatti, E. P., FernandezLafuente, R., Manoel, E. A., Freire, D. M. G., \& Pinto, J. C. (2019). Effects of reaction operation policies on properties of core-shell polymer supports used for preparation of highly active biocatalysts. Macromolecular Reaction Engineering, 13(1), 1800055. http://dx.doi.org/10.1002/mren.201800055.

10. Shakerian, F., Kim, K.-H., Kwon, E., Szulejko, J. E., Kumar, P., Dadfarnia, S., \& Haji Shabani, A. M. (2016). Advanced polymeric materials: synthesis and analytical application of ion imprinted polymers as selective sorbents for solid phase extraction of metal ions. Trends in Analytical Chemistry, 83, 55-69. http://dx.doi.org/10.1016/j.trac.2016.08.001.

11. Castanharo, J. A., Ferreira, I. L. M., Silva, M. R., \& Costa, M. A. (2018). Core-shell magnetic particles obtained by seeded suspension polymerization of acrylic monomers. Polímeros Ciência e Tecnologia, 28(5), 460-467. http://dx.doi. org/10.1590/0104-1428.10517.

12. Castanharo, J. A., Ferreira, I. L. M., Costa, M. A. S., Silva, M. R., Costa, G. M., \& Oliveira, M. G. (2015). Magnetic microspheres based on poly(divinylbenzene-co-methyl methacrylate) obtained by suspension polymerization. Polimeros: Ciência e Tecnologia, 25(2), 192-199. http://dx.doi.org/10.1590/0104-1428.1666.

13. Souza, F. S., Costa, M. A. S., Maria, L. C. S., Mello, I. L., Silva, M. R., \& Wang, S. H. (2013). Síntese e caracterização de copolímeros reticulados à base de estireno, divinilbenzeno $\mathrm{e}$ metacrilato de metila com propriedades magnéticas. Polímeros: Ciência e Tecnologia, 23(1), 82-90. http://dx.doi.org/10.1590/ S0104-14282013005000004.

14. Simplicio, S., Lucas, E. F., Costa, M. A. S., Costa, L. C., \& Santa Maria, L. C. (2014). Thermal resistance of magnetic polymeric composites based on styrene, divinylbenzene, and $\mathrm{Ni}$ and Co particles. Journal of Thermal Analysis and Calorimetry, 117(1), 369-375. http://dx.doi.org/10.1007/s10973-014-3703-9.
15. Simplício, S., Maria, L. C. S., Costa, M. A. S., Lucas, E. F., Queirós, Y. G. C., Marques, L. R. S., Costa, L. C., Hui, W. S., \& Silva, M. R. (2013). Removal of phenol from aqueous solutions by polymeric composites containing $\mathrm{Ni}$ and $\mathrm{Co}$ particles. Polímeros: Ciência e Tecnologia, 23(5), 590-596. http://dx.doi.org/10.4322/polimeros.2013.092.

16. Evaristo, A. A. A., Santos, K. C. R., Costa, L. C., \& Marques, M. R. C. (2013). Evaluation of ion exchange resins for recovery of metals from electroplating sludge. Polymer Bulletin, 70(8), 2239-2255. http://dx.doi.org/10.1007/s00289-013-0944-x.

17. Valle, A. S. S., Marques, M. R. C., Costa, L. C., Maria, L. C. S., Aguiar, A. P., \& Merçon, F. (2013). Evaluation of bactericidal action of 2-vinylpiridine copolymers containing quaternary ammonium groups and their charge transfer complexes. Polímeros Ciência e Tecnologia, 23(2), 152-160. http://dx.doi. org/10.1590/S0104-14282013005000023.

18. Costa, L. C., Marques, M. R. C., Tiosso, R. B., Cantarim, J. P., \& Merçon, F. (2012). Evaluation of the biocidal activity of hypercrosslinked resins containing dithiocarbamate groups. Macromolecular Symposia, 319(1), 121-128. http://dx.doi. org/10.1002/masy.201100175.

19. Valle, A. S. S., Costa, L. C., Marques, M. R. C., Silva, C. L. P., Maria, L. C. S., Merçon, F., \& Aguiar, A. P. (2011). Preparação de copolímeros à base de 2-vinilpiridina com propriedades bactericidas. Quimica Nova, 34(4), 577-583. http://dx.doi. org/10.1590/S0100-40422011000400005.

20. Gangadharan, D., Harshvardan, K., Gnanasekar, G., Dixit, D., Popat, K. M., \& Anand, P. S. (2010). Polymeric microspheres containing silver nanoparticles as a bactericidal agent for water disinfection. Water Research, 44(18), 5481-5487. http://dx.doi org/10.1016/j.watres.2010.06.057. PMid:20673945.

21. Santa Maria, L. C., Oliveira, R. O., Mercon, F., Borges, M. E. R. S. P., Barud, H. S., Ribeiro, S. J. L., Messaddeq, Y., \& Wang, S. H. (2010). Preparation and bactericidal effect of composites based on crosslinked copolymers containing silver nanoparticles. Polímeros: Ciência e Tecnologia, 20(3), $227-$ 230. http://dx.doi.org/10.1590/S0104-14282010005000028.

22. Ahmed, A. E. I., Hay, J. N., Bushell, M. E., Wardell, J. N., \& Cavalli, G. (2008). Biocidal polymers (I): preparation and biological activity of some novel biocidal polymers based on uramil and its azo-dyes. Reactive \& Functional Polymers, 68(1), 248-260. http://dx.doi.org/10.1016/j.reactfunctpolym.2007.09.004

23. Jandrey, A. C., Aguiar, A. P., Aguiar, M. R. M. P., Santa Maria, L. C., Mazzei, J. L., \& Felzenszwalb, I. (2007). Iodine-poly(2vinylpyridine-co-styrene-co-divinylbenzene) charge transfer complexes with antibacterial activity. European Polymer Journal, 43(11), 4712-4718. http://dx.doi.org/10.1016/j. eurpolymj.2007.07.042.

24. Yee, M. S.-L., Khiew, P. S., Tan, Y. F., Kok, Y.-Y., Cheong, K. W., Chiu, W. S., \& Leong, C.-O. (2014). Potent antifouling silver-polymer nanocomposite microspheres using ionexchange resin as templating matrix. Colloids and Surfaces A, Physicochemical and Engineering Aspects, 457(1), 382-391. http://dx.doi.org/10.1016/j.colsurfa.2014.06.010.

25. Qu, X., Alvarez, P. J. J., \& Li, Q. (2013). Applications of nanotechnology in water and wastewater treatment. Water Research, 47(12), 3931-3946. http://dx.doi.org/10.1016/j. watres.2012.09.058. PMid:23571110.

26. Mthombeni, N. H., Mpenyana-Monyatsi, L., Onyango, M. S., \& Momba, M. N. B. (2012). Breakthrough analysis for water disinfection using silver nanoparticles coated resin beads in fixed-bed column. Journal of Hazardous Materials, 217-218(1), 133-140. http://dx.doi.org/10.1016/j.jhazmat.2012.03.004. PMid:22459979.

27. Kamrupi, I. R., Phukon, P., Konwer, B. K., \& Dolui, S. K. (2011). Synthesis of silver-polystyrene nanocomposite 
particles using water in supercritical carbon dioxide medium and its antimicrobial activity. The Journal of Supercritical Fluids, 55(3), 1089-1094. http://dx.doi.org/10.1016/j. supflu.2010.09.027.

28. Denyer, S., \& Stewart, G. S. A. B. (1998). Mechanisms of action of disinfectants. International Biodeterioration \& Biodegradation, 41(3-4), 261-268. http://dx.doi.org/10.1016/ S0964-8305(98)00023-7.

29. Popa, A., Davidescu, C. M., Trif, R., Ilia, G., Iliescu, S., \& Dehelean, G. (2003). Study of quaternary 'onium' salts grafted on polymers: antibacterial activity of quaternary phosphonium salts grafted on 'gel-type' styrene-divinylbenzene copolymers. Reactive \& Functional Polymers, 55(2), 151-158. http://dx.doi. org/10.1016/S1381-5148(02)00224-9.

30. Liang, J., Chen, Y., Barnes, K., Wu, R., Worley, S. D., \& Huang, T. S. (2006). N-halamine/quat siloxane copolymers for use in biocidal coatings. Biomaterials, 27(11), 2495-2501. http:// dx.doi.org/10.1016/j.biomaterials.2005.11.020.

31. Pal, S., Tak, Y. K., \& Song, J. M. (2007). Does the antibacterial activity of silver nanoparticles depend on the shape of the nanoparticle? A study of the Gram-negative bacterium Escherichia coli. Applied and Environmental Microbiology, 73(6), 1712-1720. http://dx.doi.org/10.1128/AEM.02218-06. PMid:17261510.

32. Thiel, J., Pakstis, L., Buzby, S., Raffi, M., Ni, C., Pochan, D. J. \& Shah, S. I. (2007). Antibacterial Properties of SilverDoped Titania. Nano Micro Small , 3(5), 799-803. https:// doi.org/1.1002/smll.200600481

Received: Mar. 07, 2019

Revised: Sept. 21, 2019

Accepted: Oct. 11, 2019 